\title{
Revista Estudos Feministas: 26 anos de publicação
}

\begin{abstract}
O que mudou no tempo e no espaço, de Simone de Beauvoir até nós, quando ela nos falava em minorias? Como editoras da Revista Estudos Feministas e participando da organização de 11 edições do Seminário Internacional Fazendo Gênero, podemos afirmar que o feminismo se consolidou enquanto consciência crítica, erótica e verbal. Foi com essa perspectiva que recebemos o estudo publicado pela editoria Elsevier referente aos últimos 20 anos, Gender in the Global Research Landscape, o qual revela que o Brasil lidera - ranking mundial de igualdade de gênero na produção científica, levando em conta artigos publicados indexados em bases de dados científicas. Isso significa, em volume, 153.967 artigos publicados por mulheres entre 2011 e 2015 (ficaremos atentas para a possível continuidade da pesquisa), totalizando $49 \%$ dos artigos publicados no país, no período. Este índice é o mais alto de todos os países pesquisados, equiparando-se em percentual apenas a Portugal, cujo número absoluto é muito menor: menos de $20 \%$ do total brasileiro.
\end{abstract}

Esses números não foram sempre tão altos. Entre $1996 \mathrm{e}$ 2000 , a produção das mulheres correspondia a $38 \%$ do total da produção científica brasileira, indicando, portanto, um aumento de $11 \%$ nos dados mais recentes. As mulheres brasileiras são, segundo os dados, em sua maioria pesquisadoras nas áreas de medicina, agricultura, biologia, biologia molecular, bioquímica e genética. Contudo, nem todas as conclusões da pesquisa apontam para a igualdade. Apesar de haver equilíbrio no número total de publicações, as mulheres ainda são citadas com menos frequência do que os homens no Brasil, e a grande maioria das patentes levam nomes de homens, evidenciando marcas relevantes de desigualdade de gênero no campo da produção científica.

A Revista Estudos Feministas, assim como Cadernos Pagu e vários outros periódicos dedicados à publicação de estudos de gênero e feministas no Brasil, que abrem seus espaços

(D) Esta obra está sob licença Creative Commons. 
para as pesquisadoras das áreas de ciências humanas, de letras e artes, podem se orgulhar pelo papel que têm desempenhado na construção de indicadores que atestam a conquista de uma posição de liderança do país no ranking mundial de igualdade de gênero na produção científica.

Numa primeira pesquisa sistemática realizada na $R E F$, quando completara 10 anos de publicação, as autoras Débora Diniz e Paula Foltran (2004) revelavam a expressiva predominância de autorias individuais nos artigos publicados pela revista até então, a ausência quase total de publicações das feministas vizinhas da América Latina em suas páginas e também de artigos produzidos por autores homens, questão que já fora mencionada por Lena Lavinas (1992) no relevante editorial do primeiro número da revista. Analisando rapidamente a REF quando completa 26 anos de publicação, podemos perceber que muita coisa mudou: os artigos são, em sua maioria produzidos em parcerias de autoras/es, há uma expressiva produção de estudos publicados por pesquisadoras da América Latina de língua espanhola e autores homens se fazem cada vez mais presentes com publicações nas páginas da revista.

Uma mudança marcante diz respeito à diversificação dos temas que alimentam as reflexões e pesquisas que acompanham as práticas e movimentos sociais de vários matizes e que se refletem na produção acadêmica publicada nas revistas de estudos de gênero e feministas na atualidade. Diversificação refletida também na REF, como mostra este número do periódico. No entanto, muitos temas permanecem como objeto constante de estudos, pontuando questões que não foram resolvidas e continuam narrando desigualdades de gênero. Uma delas, refletida expressivamente nesta edição, é a questão do trabalho, que inicia com a tradução do verbete Domesticação do Trabalho, produzido pela socióloga alemã Frigga Haug (2001) para o Dicionário Histórico-crítico do Marxismo, editado pelo Instituto de Pesquisa da Teoria Crítica de Berlim. No ano em que se comemoram dois séculos do nascimento de Karl Marx, julgamos conveniente aceitar a generosa oferta da tradutora desse texto para publicação na $R E F$, precedendo os diversos artigos que refletem sobre desdobramentos atuais do tema: condições diferenciais de trabalho num universo profissional feminizado; atuação de mulheres em núcleos de inovações tecnológicas; a reedição de modelo tradicional nas relações de gênero entre profissionais; a difícil divisão do trabalho doméstico, com a responsabilização das mulheres pelos cuidados, ocasionando suas múltiplas jornadas de trabalho.

Pesquisas brasileiras nos trazem para o segundo número do volume 26 que a revista publica em 2018, com reflexões sobre os movimentos feministas na primeira república; paternidade e paternagem em famílias patrifocais; que 
questionam a desqualificação do feminismo e dos estudos de sexualidade pelo discurso cristão da chamada "ideologia de gênero"; percorrem o turismo sexual, as vivências e as trajetórias de sociais por ruas e cidades; visibilizam as mulheres negras nos carnavais paulistanos; revelam as artimanhas da arte com suas imagens sado-masoquistas e fetichistas; analisam a escrita da mulher e a mulher escrita; reescrevem as memórias dos corpos e as subjetividades feministas na dramaticidade da ópera; apresentam o artivismo e a produção de subjetividades; ressignificam a Marquesa de Santos; historicizam o gênero na história das revistas médicas paulistas e ousam o discurso crítico com as novas regras na publicidade de absorventes.

Este número apresenta também estudos de caso e ações de combate à violência e problematizam o feminicídio e as trajetórias do sujeito político feminista em sua perspectiva interseccional. Tratam-se de temas incontornáveis, devido às violências que as mulheres continuam sofrendo no cotidiano. $E$ se tornam ainda mais oportunos no momento de uma intensa luta dos movimentos sociais pelo esclarecimento dos fatos que resultaram no assassinato da vereadora Marielle Franco ocorrido em 14 de março de 2018 . Ela era vereadora do Estado do Rio de Janeiro pelo Partido Socialismo e Liberdade (PSOL), tinha apenas 39 anos, era socióloga, feminista, militante dos direitos humanos e lésbica. Oriunda de uma das favelas do Rio de Janeiro, lutava pela descriminalização da juventude negra no Brasil, que apresenta índices vergonhosos de assassinatos de homens negros, os quais constituem a grande maioria da população encarcerada no país. O assassinato de Marielle e do trabalhador que a conduzia ocorreu em meio às polêmicas suscitadas pela ocupação repetida de favelas da cidade do Rio de Janeiro pelo exército, com o pretexto de combate ao crime organizado em torno do tráfico de drogas. O chamado "combate ao crime" que põe em risco a vida das populações locais, nesses territórios vulnerabilizados de nossas cidades.

Ao lado do diálogo que estabelecemos com Paulina Chiziane, onde nos fala de guerras, mulheres e memórias, estão nossas "hermanas" da América do Sul, com suas sólidas pesquisas sobre trabalho social e estudos de gênero e feministas, reivindicando espaços próprios na produção do conhecimento cientifico, a sobrecarga do trabalho das mulheres inseridas nos programas sociais da Argentina e a reorganização do modelo doméstico em relação às responsabilidades masculinas e femininas.

Nesse fluxo de muitos textos que vêm e vão, nesse movimento de leituras a teorias, a história e a crítica se escrevem. Em 2015, 2016 e 2017 podem ser lidas e organizadas em nossos sumários, falas de gênero sobre as vicissitudes da história presente, como as narradas e visualizadas no premiado documentário de Maria Augusta Ramos (2018), mostrando ao 
mundo o processo do impeachment contra Dilma Rousseff, as entranhas da mídia, da misoginia e do Golpe. Tornando-se matéria de reflexão no calor da hora e sementes para futuras narrativas, pesquisas sobre a complexidade de 2018, as censuras e os desajustes dos poderes legislativo, executivo e judiciário; as arbitrariedades que têm se abatido sobre importantes lideranças políticas historicamente comprometidas com as lutas pela igualdade e pela justiça; os poderes da grande mídia; a violência contra as mulheres; as ruas e seus movimentos; as organizações dos acampamentos rurais e urbanos; a união dos sindicatos de trabalhadores e movimentos sociais em defesa de direitos sociais arduamente conquistados. Direitos sociais em conquistas ainda parciais, agora submetidos ao desmanche protagonizado pelo autoritarismo das forças que tomaram o poder no país, em sua adesão incondicional ao ideário neoliberal, responsável pelo agravamento das desigualdades sociais locais e globais. Neoliberalismo que começa a ser questionado pelas próprias instituições internacionais conservadoras que o recomendavam/ impunham.

Finalmente, ressaltamos que, enquanto fechamos esse número e organizamos os seguintes, permanecemos - junto com milhares de pessoas por este país afora - com uma questão sofrida nas nossas mentes: AFINAL, QUEM MATOU MARIELLE? Quem destruiu seus sonhos por um mundo melhor, mais humano, mais justo?

\section{Referências}

DINIZ, Débora e FOLTRAN, Paula. "Gênero e feminismo no Brasil: uma análise da Revista Estudos Feministas". Revista Estudos Feministas. Florianópolis, V. 12, N. Especial, 2004, 245-253.

HAUG, Frigga."Hausfrauisierung(H)". Historisch-Kritisches Wörterbuch des Marxismus, HKWM. Band 5, Berlin 2001, 1209-1215.

LAVINAS, Lena. "Editorial". Revista Estudos Feministas. Rio de Janeiro, N. 0, 1992, p. 3-4.

RAMOS, Maria Augusta. O Processo. Documentário, cor, 137 min. Direção de Maria Augusta Ramos; Produção de Leonardo Mecchi; Edição de Karen Akerman. 2018.

Tânia Regina Oliveira Ramos

Mara Coelho de Souza Lago Luzinete Simões Minella

Universidade Federal de Santa Catarina, Florianópolis, SC, Brasil 